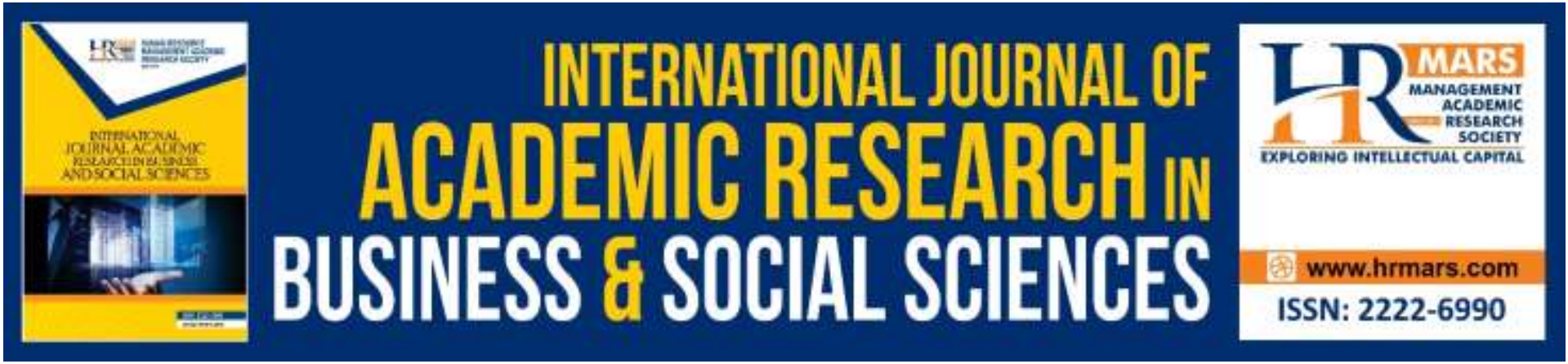

\title{
Measuring Internet Addiction among Multiracial Youths in Malaysia
}

Siti Zobidah Omar, Nurul Farhana Saharuddin, Jusang Bolong

To Link this Article: http://dx.doi.org/10.6007/IJARBSS/v9-i9/6340

DOI: $10.6007 /$ IJARBSS/v9-i9/6340

Received: 28 July 2019, Revised: 20 August 2019, Accepted: 28 August 2019

Published Online: 02 September 2019

In-Text Citation: (Omar, Saharuddin, \& Bolong, 2019)

To Cite this Article: Omar, S. Z., Saharuddin, N. F., \& Bolong, J. (2019). Measuring Internet Addiction among Multiracial Youths in Malaysia. International Journal of Academic Research in Business and Social Sciences, 9(9), 654-662.

Copyright: (C) 2019 The Author(s)

Published by Human Resource Management Academic Research Society (www.hrmars.com)

This article is published under the Creative Commons Attribution (CC BY 4.0) license. Anyone may reproduce, distribute, translate and create derivative works of this article (for both commercial and non-commercial purposes), subject to full attribution to the original publication and authors. The full terms of this license may be seen

at: http://creativecommons.org/licences/by/4.0/legalcode

Vol. 9, No. 9, 2019, Pg. 654 - 662

http://hrmars.com/index.php/pages/detail/IJARBSS

JOURNAL HOMEPAGE

Full Terms \& Conditions of access and use can be found at http://hrmars.com/index.php/pages/detail/publication-ethics 


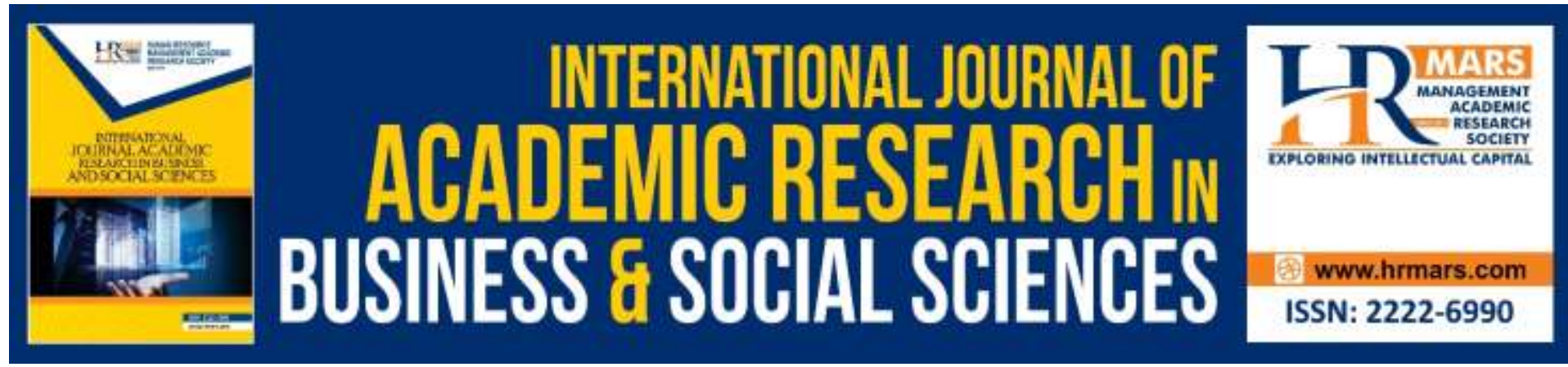

\title{
Measuring Internet Addiction among Multiracial Youths in Malaysia
}

\author{
Siti Zobidah Omar ${ }^{1}$, Nurul Farhana Saharuddin ${ }^{1}$, \\ Jusang Bolong ${ }^{2}$ \\ ${ }^{1}$ Institute for Social Science Studies, Universiti Putra Malaysia, ${ }^{2}$ Faculty of Modern Language \\ and Communication, Universiti Putra Malaysia
}

\begin{abstract}
Internet addiction among youths is a serious issue in Malaysia. Hence, this study aims to examine the level of internet addiction among multiracial youths in Malaysia. A total of 400 respondents was collected from the four main zones in Malaysia. The study concluded that several concerns have surfaced due to the impact from internet addiction, these multiracial youths perceived the internet to be an important part of their life, they felt left out without it, and they assumed that life is boring without the internet. Several recommendations are highlighted in light that it can be a basis for future planning in reducing internet addiction among future generations in Malaysia.
\end{abstract}

Keyword: Internet Addiction, Youth, Youth Development.

\section{Introduction}

The use of internet in Malaysia has been growing rapidly. A survey on broadband subscription in Malaysia has demonstrated a penetration rate of $103.6 \%$ (per inhabitant) and $81.8 \%$ (per household). Despite the positive impacts resulting from the use of internet, its excessive usage may also result in negative influences such as internet usage addiction. Internet addiction refers to the excessive and outrageous use of the internet, which eventually result in symptoms of being anti-social like being dishonest, having poor achievement, and lethargy. With the advancement of the internet and technology, the cyber world has embodied a network of virtual communications and connections as a liaison for people to get connected without restrictions. The internet brings a lot of changes to the society, people are relying too much on the internet due to the simple click of a button and countless information can be obtained across the globe.

\section{The Impact of Internet Addiction on Youths}

In the past, internet addiction has been proven to cause individuals to lose control over their internet usage, which eventually result in psychological, social, school, and work difficulties in their personal life (Davis, 2001). Griffiths (2000) claimed that individuals with irrational cognitive assumptions about themselves were likely to show symptoms of lower self-esteem and be involved in addictive behaviors to relieve themselves temporarily of their negative 
cognitive assumptions about self. Furthermore, symptoms of low self-esteem, low motivation, and social isolation are among psychological problems related to the overuse of internet. The ease of access and affordability of internet subscription services also led to internet addiction (Yang, 2005). In a study by Beutel et. al (2017), they found that loneliness may result from the excessive use of internet. Loneliness is related to a number of mental issues such as depression, anxiety, and suicide ideation. Loneliness also influences people to over rely on the internet for social support, in this situation they risk their social life by being addicted to the internet (Yu-Chun et. al, 2008). Internet usage addiction is especially eminent among youth generations because past studies have found that undergraduate students are susceptible to be addicted to internet usage as they have more leisure time and lack parental monitoring. (Jiang, 2014; Stavropoulos et. al, 2013).

Internet addiction is reported to instigate negative consequences in the daily routines among youths (Chou, 2000). It is noted that the amount of hours spent on the internet would cause the individual to be addicted to the internet, as they spend less time with their family and friends, these individuals are being reprimanded on their anti-social behavior but to no avail it was difficult to limit their internet usage (Chak et. al, 2004). Internet addiction is known to trigger insomnia among youths, disrupting their diet and limiting their physical activities (Cao et. al, 2006). Past studies by Tan (2016), Chen (2016), and Lam (2014) have examined the relationship between sleep quality and the overuse of internet, all three studies concluded that youths diagnosed with sleep difficulties were predisposed to incessant internet addiction while another study by Choi et al. (2009) found that internet addicted individuals suffered from disruptions to their circadian rhythms. Moreover, Young (2007) noted that internet addiction result in poor academic performances among students due to them being more interested on spending their time on surfing the internet rather than focusing on their tasks as a student.

\section{Methodology}

Method

This study uses quantitative methods and the data collection process was conducted from January to August of 2018. About 400 respondents were selected based on stratified random sampling to ensure that these samples are represented by the current proportion of races in Malaysia. The respondents were selected from the rural and urban areas of Kedah, Terengganu, Johor, and Sabah. Each state was represented by 100 respondents. . Drawing on current ratio of races by the Statistical Department of Malaysia (2015), the Malaysian population consists of $56 \%$ Malay, $24 \%$ Chinese, $13 \%$ Sabahan/Sarawakian, and $7 \%$ Indian. Thus, the sampled respondents are represented by 280 Malays, 120 Chinese, 65 Sabahan Bumiputeras, and 35 Indians. These respondents volunteered to be part of this study, questionnaires were administered and collected back on the same day. They took approximately 20 minutes to complete the survey.

\section{Instrument}

The study's questionnaire is divided into three parts. Part A encloses the respondents' demographic information, which includes gender, age, races, education level, household number, job status, income per month, and the duration of residence in that area. For Part B, the respondents were questioned about their internet usage experience, online activities, and 
online surfing behaviors such as internet usage frequency (less than once a month to several times a day), duration (less than 30 minutes to more than 4 hours daily), problems that arise from internet usage, and motivations (or reasons for using the internet, e.g., Facebooking, messaging, seeking information for university projects/assignments, etc.). The final section, which is part C, measures the level of internet addiction through scores using a 20-item Internet Addiction measurement. Each item is measured using a 5-point Likert scale.

\section{Analysis}

The data from this study was then analyzed through SPSS software. Descriptive analysis and inference like frequency, percentage, mean, and standard deviation were analyzed to answer the research's objective.

\section{Results and Discussion}

Demographic Factor

Majority of the respondents are female (66.5\%). About $41.3 \%$ of the respondents fall within the $21-25$ years old age group, followed by those below 20 years old $(26.5 \%), 26-30$ years old $(16.8 \%)$, and above 31 years old (16.8\%). The mean score recorded for age group was 24.5 years old.

In terms of education level, most of respondents finished their tertiary education (56\%), followed by upper secondary school (39.5\%), lower secondary school (2.3\%), and primary school (2\%). Most of the respondents have between 4-5 household members (42.3\%), while $32 \%$ of them have 6 or more household members 32\%, and another $25.8 \%$ have 3 or less household members. With regard to their job status, more than half have permanent jobs (54\%) whereas the other $18.8 \%$ were unemployed.

The monthly incomes generated by these youths are mostly below RM1000 (55.4\%) while the other $44.6 \%$ earned more than RM1001. These youths have resided in the area for more than 21 years (refer to Table 1 ). 


\begin{tabular}{|c|c|c|c|}
\hline Factors & Frequency & Percentage & Mean score \\
\hline Age (years) & & & 24.5 \\
\hline$<20$ & 106 & 26.5 & \\
\hline $21-25$ & 165 & 41.3 & \\
\hline $26-30$ & 67 & 16.8 & \\
\hline$>31$ & 62 & 15.5 & \\
\hline \multicolumn{4}{|l|}{ Gender } \\
\hline Male & 134 & 33.5 & \\
\hline Female & 266 & 66.5 & \\
\hline \multicolumn{4}{|l|}{ Education level } \\
\hline Never been to school & 1 & .3 & \\
\hline Primary school & 8 & 2.0 & \\
\hline Lower secondary school & 9 & 2.3 & \\
\hline Upper secondary school & 158 & 39.5 & \\
\hline Tertiary & 224 & 56.0 & \\
\hline \multicolumn{4}{|l|}{ Number of household members } \\
\hline 3 or less & 103 & 25.8 & \\
\hline $4-5$ & 169 & 42.3 & \\
\hline 6 or more & 128 & 32.0 & \\
\hline \multicolumn{4}{|l|}{ Job status } \\
\hline Permanent & 216 & 54.0 & \\
\hline Contract & 74 & 18.5 & \\
\hline Self-employed & 35 & 8.8 & \\
\hline Unemployed & 75 & 18.8 & \\
\hline Income per month $(n=325)$ & & & RM1,472.99 \\
\hline$<$ RM1000 & 180 & 55.4 & \\
\hline >RM1001 & 145 & 44.6 & \\
\hline Duration of staying in the area (years) & & & 16.1 \\
\hline 10 or less & 132 & 33.0 & \\
\hline $11-20$ & 115 & 28.8 & \\
\hline 21 or more & 153 & 38.3 & \\
\hline
\end{tabular}

Table 1: Demographic factors

\section{Statement Measuring Internet Addiction}

Table 2 demonstrates the item statements measuring internet addiction among multiracial youths in Malaysia. The statement "the internet has become part of my daily routine" ( $M=$ 4.28) yielded the highest mean score, followed by statement "I feel left out when I'm not browsing the internet even for a while" ( $M=3.60)$, and "I feel that life without Internet must be boring" ( $M=3.58)$. The lowest mean score however was recorded by the statement "I refuse to carry out my daily responsibilities due to spending more time on the Internet" ( $M=$ 1.93). 


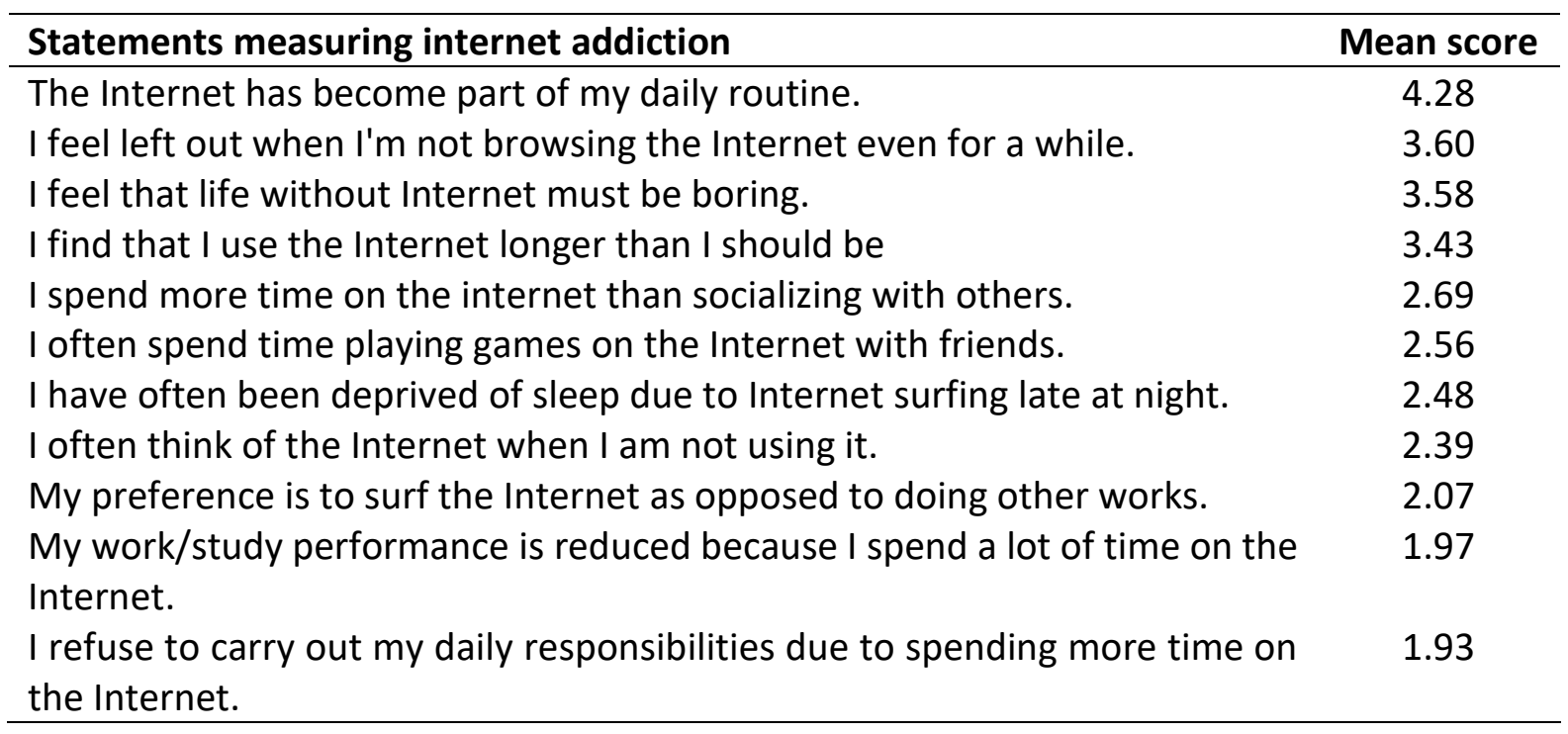

Table 2: Internet Addiction among Malaysian Youth

\section{Recommendation}

Several recommendations are highlighted to reduce internet addiction among youths. Firstly, community activities should be highlighted and encouraged among youths for their participation because it is considered as a better time passing to reduce internet addiction. An excessive use of the internet reduces human interactions in the real world and promotes low mobility, which trigger social isolation (Chao, 2018). Therefore, the best solution would be to encourage youth involvement in community activities such as volunteering programs, extracurricular activities, and societal events will prevent them from turning anti-social. Moreover, the more time they spend interacting with their surroundings will also reduce the amount of time they spend on the internet.

Secondly, at their age, youths need to be physically and mentally healthy. Thus, healthy activities such as wellness programs or mental health programs can help individuals suffering from internet addiction disorders. Mental health programs offer expert consultations from legal therapists who can give good counselling and help solve problems regarding internet addiction.

Thirdly, awareness on internet addiction should be rationalized. Awareness on the symptoms of internet addiction is vital among university students and counsellors for a timely prevention and intervention. Internet addiction affects cyber ethical issues (accuracy, property, access), hence cyber ethics awareness should be emphasized in schools through campaigns or seminars. Internet addiction elicits youth to spend more time browsing the virtual world rather than focusing on their studies or jobs, which later affects their academic achievement or job productivity. In response to this issue, a proper time management and self-discipline are needed to gear them into time management and limit their internet usage while at the same time encourage them to be more involved in offline activities.

\section{Conclusion}

The internet is an advanced form of technology that allows people to have a wider access to the virtual world. People nowadays have countless and borderless access to information with just a click. Albeit the positive use it has, the internet also triggers an undesirable social 
disease called internet addiction. The overuse of internet has its consequences, it slowly affects people psychologically; their lifestyle; academic/job performance, productivities and more. In realizing this issue, the current study examined internet addiction among the most active internet users in Malaysia - youths. Based on the data obtained from the four main zones in Malaysia, the study concluded that concerns arise as these youths perceived the internet to be an important part of their life. They also stated that they felt left out if they are not connected to the virtual world and ominously, some youths even demonstrated a high reliance on the internet by stating that their life is boring without the internet. Therefore, several recommendations are made related to participation in community activities, mental health programs, proper time management, and self-discipline.

\section{References}

Beard, K. (2002). Internet addiction: current status and implications for employees' Journal.

Beutel, M. K. (2017). Loneliness in the General Population: Prevalence, Determinants and Relations to Mental Health. BMC Psychiatry, 17, 97.

Burnay, J. B. (215). Which Psychological Factors Influence Internet Addiction? Evidence through an Integrative Model. Computers in Human Behavior , 43, , 28-34.

Cao, F. \&. (2006). internet addiction among Chinese adolescents: prevalence and psychological features. Journal compilation (C) Blackwell Publishing Ltd.

Chak, K. \&. (2004). Shyness and locus of control as predictors of internet addiction and internet use. CyberPsychology \& Behavior; 7 (5), 59-70.

Chen, K. T. (2004). Internet dependency: its impact on online behavioral patterns in Ecommerce. Human System Managment 23 (1) , 49-58.

Chen, Y. G. (2016). Sleep problems and internet addiction among children and adolescents: a longitudinal study. Journal Sleep Resources (4), 458 - 465.

Choi K, S. H. (2009). Internet overuse and excessive daytime sleepiness in adolescents. Psychiatry Clin. Neurosci. 63, 455 - 462.

Chou, C. \&. (2000). Internet Addiction, Usage, Gratification, and Pleasure Experience: The Taiwan College Students' Case. Computers \& Education, 35, 65-80.

Craig, R. (1995). The role of personality in understanding substance abuse. Alcohol Treatment Quarterly 13, 17-27.

Davis, R. A. (2001). A cognitive-behavioral model of pathological internet use. Computers in Human Behavior, 17, 187 - 195.

Douglas AC, M. J. (2008). Internet addiction: meta-synthesis of qualitative research for the decade 1996-2006. Computer Human Behavior, 24(6):30, 27 - 44.

Fennell, M. (1997). Low self-esteem: a cognitive perspective. Behaviour Cognitive Psychother. 25 (1), 1-26.

Griffiths, M. (2000). Does Internet and computer" addiction" exist? Some case study evidence. Cyber psychology Behaviour. 3 (2), 211-218.

Jiang, Q. (2014). Internet addiction among young people in China: Internet connectedness, online gaming, and academic performance decrement. Internet Research, 24(1), 2-20.

Kandell, J. J. (1998). Internet Addiction on Campus: The Vulnerability of College Students. Cyber Psychology \& Behavior, 1,, 11 -17.

$\mathrm{Ko} \mathrm{CH}, \mathrm{Y}$. J. (2012). The association between internet addiction and psychiatric disorder: a review of the literature. Europe Psychiatry, 27(1), 1-8.

Kraut, R. K. (2002). internet paradox revisited. Journal of Social issues, 58, 49-74. 
Lam \& L.T. (2014). Internet gaming addiction, problematic use of the internet, and sleep problems: a systematic review. Curr. Psychiatry Rep. (4), 444.

Lehenbauer Baum, M. K. (215). Addiction and engagement: An explorative study toward classification criteria for Internet gaming disorder. Cyberpsychology, Behavior, and Social Networking, 18(6), 343 - 349.

Manfred E. Beutel, E. M. (2017). Loneliness in the general population: prevalence, determinants and relations to mental health. BMC Psychiatry 17(1) , 1-7.

Melvyn W.B. Zhang, B. X. (2017). Internet addiction and sleep quality among Vietnamese youths. Asian Journal of Psychiatry (28), 15-20.

$\mathrm{Nie}$, J. Z. (2016). Impaired inhibition and working memory in response to internet-related words among adolescents with internet addiction: A comparison with attentiondeficit/hyperactivity disorder. Psychiatry Research, 236, 28 - 34.

Niemz K, G. M. (2009). Prevalence of Pathological internet use among University student and correlation with self-esteem, the General Health Questionnaire (GHQ) and Disinhibition. Cyberpsychology and Behavior, Vol 8, No 7, 443 - 450.

Niemz, K. G. (2005). Prevalence of Pathological internet Use among University Students and Correlations with Self-Esteem, the General Health Questionnaire (GHQ), and Disinhibition. Cyberpsychology and Behavior, 8, 443-450.

Odaci, H. (2011). Academic self-efficacy and academic procrastination as predictors of problematic internet use in university students. Computers \& Education, 57(1), 11091113.

Pontes, H. M. (2015). Clinical psychology of internet addiction: A review of its conceptualization, prevalence, neuronal processes, and implications for treatment. Neuroscience and Neuro economics, 4, 11-23.

Rosenberg, M. (1965). The measurement of self-esteem, Society and the adolescent selfimage. Princeton , 16-36.

Ryan, K. (2014). Internet Addiction Affects 6\% of People Worldwide.

Ryan, R. M. (2009). Promoting self-determined school engagement: Motivation, learning, and well-being. Handbook of motivation at school, 171-195.

Salmela Aro, K. U. (2017). The dark side of Internet use: Two longitudinal studies of excessive internet use, depressive symptoms, school burnout and engagement among Finnish early and late adolescents. Journal of Youth and Adolescents 46(2), 343 - 357.

Skinner, E. A. (2009). A motivational perspective on engagement and disaffection: Conceptualization and assessment of children's behavioral and emotional participation in academic activities in the classroom. Educational and Psychological Measurement 69 (3), 493 - 525.

Skinner, E. A. (2009). Engagement as an organizational construct in the dynamics of motivational development. Handbook of motivation at school , 223-245.

Soule, L. S. (2003). Exploring Internet Addiction: Demographic Characteristics and Stereo Types of Heavy Internet Users. Journal of Computer Information Systems 44, 64 - 73.

Stavropoulos, V. A. S. (2013). Recognizing internet addiction: Prevalence and relationship to academic achievement in adolescents enrolled in urban and rural Greek high schools. Journal of Adolescence, 36(3) , 565-576.

Tan, Y. C. (2016). Exploring associations between problematic internet use, depressive symptoms and sleep disturbance among southern chinese adolescents. International Journal Environment Resource Public Health 14. 
Weiser, E. (2001). The functions of internet use and their social and psychological consequences. CyberPsychology \& Behavior, 4, 723-743.

Whang, L. S, L. S. (2003). internet over-users' psychological profiles: a behavior sampling analysis on internet addiction. Cyber Psychology \& Behavior, 6(1), 43-50.

Widyanto, L. (2006). The psychometric Properties of the Internet Addiction Test. CyberPsychology and Behavior, 1, 443-450.

Yang, C. K. C. M. H. S. (2005). SCL-90-R and 16PF profiles of senior high school students with excessive internet use. Can. J. Psychiatry 50 (7), 407-414.

Yao-Guo, G. L. Y. L. (2006). A research on emotion and personality characteristics in junior high school students with internet addiction disorders. Chinese Journal of Clinical Psychology, 14, 153-155.

Young, K. S. (1996). Psychology of computer use: XL. Addictive use of the internet: a case that breaks the stereotype. Psychology Rep, 79(3), 899 - 902.

Young, K. (1998). Internet addiction: The emergence of a new clinical disorder. CyberPsychology \& Behavior 1, 237-244.

Young, K. S. (1998). The relationship between depression and internet addiction. Cyber psychology and Behavior, 1, 25 - 28.

Yu-Chun, Y, H. C. K. W. P. (2008). Gender Differences in Relationships of Actual and Virtual Social Support to internet Addiction Mediated through Depressive Symptoms among College Students in Taiwan. CYBERPSYCHOLOGY \& BEHAViOR Volume 11 (4), 485-487.

Yu-Chun, Y. H. C. K. W. P. (2008). Gender Differences in Relationships of Actual and Virtual Social Support to internet Addiction Mediated through Depressive Symptoms among College Students in Taiwan. CYBERPSYCHOLOGY \& BEHAVIOR Volume 11, No 4, 485 487. 